\title{
SEALING ABILITY OF CEMENTS IN ROOT CANALS PREPARED FOR INTRARADICULAR POSTS
}

\author{
CAPACIDADE SELADORA DE CIMENTOS EM CANAIS RADICULARES PREPARADOS PARA \\ PINOS INTRA-RADICULARES
}

Dirce Haruko NAKAMURA , Roberto Brandão GARCIA², Clóvis Monteiro BRAMANTE², Ivaldo Gomes de MORAES ${ }^{2}$, Norberti BERNADINELI ${ }^{2}$

\author{
1- MSc in Endodontics by Bauru Dental School, University of São Paulo, Brazil. \\ 2- Professors of the Discipline of Endodontics, Bauru Dental School, University of São Paulo, Brazil. \\ Corresponding address: Dirce Nakamura - Rua Arapongas, 4251 - Centro - Umuarama-PR - Cep.: 87502-180 \\ Received: September 10, 2004 - Modification: April 15, 2005 - Accepted: June 18, 2005
}

\begin{abstract}
$T$

his research evaluated the sealer ability of 2 temporary filling materials (white Cimpat and IRM) and 1 restorative cement (glass ionomer), in canals prepared for root posts. Sixty human palatal roots of maxillary first molars were used. They were divided into 3 groups, according to the cements used: Group I (Cimpat), Group II (IRM) and Group III (glass ionomer). The roots were rendered impermeable, filled with the respective cements and soon after immersed into $0.2 \%$ Rhodamine B dye and maintained for 72 hours in an oven for $37^{\circ} \mathrm{C}$. Microleakage was measured with a light microscope, cutting the roots longitudinally in buccolingual direction. The results showed that Group I presented significantly more leakage than Groups II and III, which were not significantly different from each other.

Uniterms: Sealing; Dental cements; Dental leakage; Dental pins.
\end{abstract}

\section{RESUMO}

H

sta pesquisa avaliou a capacidade seladora de dois cimentos temporários (Cimpat branco e IRM) e um cimento restaurador em canais preparados para pinos intra-radiculares. Foram usadas 60 raízes palatinas de primeiros molares superiores humanos. Elas foram divididas em 3 grupos, conforme os cimentos usados: grupo I (Cimpat), grupo II (IRM) e grupo III (ionômero de vidro). As raízes foram impermeabilizadas, preenchidas com os respectivos cimentos e em seguida imersas em tintura de Rhodamina B a 0,2\% e mantidas por 72 horas em uma estufa a $37^{\circ} \mathrm{C}$. A micro infiltração foi mensurada com um microscópio de luz nas raízes cortadas longitudinalmente, na direção vestíbubo-lingual. Os resultados mostraram que o grupo I apresentou, de modo significante, mais infiltração do que os grupos II e III, enquanto que entre estes não houve diferença significante.

Unitermos: Selamento; Cimentos dentários; Infiltração dentária; Pinos dentários.

\section{INTRODUCTION}

The success of endodontic treatment depends on the restoration or rebuilding of teeth as fast as possible to avoid marginal microleakage, considering that the oral fluid contain microorganisms, toxins and chemical substances that infiltrate through the interface between dentin and temporary sealer, yielding contamination and along time to endodontic failure.

Several studies have been accomplished on the importance of definitive and immediate restoration of teeth with endodontic treatment (Alves, Walton, Drake ${ }^{1}$ (1998), Barthel, et al. ${ }^{2}$ (1999)).
Temporary filling cements used in Endodontics must have a sealing ability to protect the obturated canal from infiltration of oral fluids until definitive tooth restoration is performed. Holland, et al. ${ }^{11}$ (1992) studied Zinc oxide and Eugenol, Gutta-Percha, association between both materials, Zoecin, Lumicon and Cimpat with utilization of vacuum and verified that the best sealing of cavities was obtained with the use of Cimpat and Lumicon. In the routine endodontic work, IRM is frequently used, whose resistance and sealer ability have been tested in several experiments, as in the work of Polo, et al. ${ }^{15}$ (1996), using IRM and the Cimpat simultaneously, who verified leakage exclusively in the area filled by IRM. 
Nowadays, endodontists are worried about the possibility of marginal leakage. Restorative cements have been used as temporary sealers, especially glass ionomer materials, mainly in cases that will be kept for a longer period. The concern with the preservation of root canal obturations that will receive root posts is valid, because many patients do not look for prosthetic treatment immediately and the remaining root canal obturation can present failure, interfering with the apical seal.

In that case, with the intention of contributing to the choice of a material with satisfactory sealer ability, the degree of marginal leakage was evaluated in root canals temporarily sealed with 3 different cements and that were previously prepared to receive posts.

\section{MATERIALAND METHODS}

Sixty human palatal roots of maxillary first molars were used, divided into 3 groups in agreement with the used cement: Group I (white Cimpat ${ }^{\mathrm{a}}$ ), Group II (IRM ${ }^{\mathrm{b}}$ ) and Group III (Vidrion $\mathrm{R}^{\mathrm{c}}$ ).

\section{Selection and preparation of the roots}

The criterion for selection of maxillary molars was based on the presence of straight palatal roots with completely formed roots. The selected teeth were maintained in $10 \%$ formalin; soon after, the crowns were removed, separating the palatal roots, with a carbide bur n. 1557 . The selected palatal roots presented a length between 14 and $16 \mathrm{~mm}$, which were radiographed in orthoradial position and mesioradial position when necessary to confirm the presence of a single canal.

\section{Instrumentation and obturation technique}

The root canals were prepared by the stepback technique, whose working length instrument was standardized in $\mathrm{n} .45$ and the final instrument was n. 60 . The tooth length was established by inserting and measuring a Kerr file n. 10 at the apical level. Then, $1 \mathrm{~mm}$ was subtracted from that measurement to obtain the working length. Initial enlargement of the canal was performed with Gates-Glidden drills n. 3, 4 and 5 during biomechanics, and the canal was constantly irrigated with $1 \%$ sodium hypochlorite at each change of instrument. A 5-ml Luer-Lock syringe with a metal beak and needle n. 4 were used. When biomechanics was concluded, the root canals were filled with EDTA (ethylene diamino tetracetic acid) maintained for 4 minutes with the purpose of removing the smear layer, followed by neutralization with $0.9 \%$ saline solution. The root canals were dried with paper points and obturated with the Sealapex sealer (calcium hydroxide-based) by the lateral condensation technique and gutta-percha. When the obturation was concluded, the excess material was removed with a heated
Paiva condenser as well as part of the obturation, up to 2/3 of the working length, to allow preparation for root posts. The roots were kept in an oven at $37^{\circ} \mathrm{C}$ and relative humidity of $100 \%$.

\section{Immersion in $\mathbf{0 . 2} \%$ Rhodamine B}

The opening of the root canals was covered with utility wax to avoid penetration of the impermeable coating into the root canal. A cylindrical toothpick was introduced in the wax to facilitate handling and maintain the root standing on a wax plate, until drying of the impermeable coating, which was achieved by utilization of fast-setting Araldite, applied in two layers on the root surface with 24-hour intervals, respecting the root canal opening. Soon after, a coat of nail varnish was applied. After 24 hours the wax was removed. A pellet of hydrophilic cotton was placed in the space prepared for the root post and the respective cements were seated with a Hollenbeck's spatula, in an extension of $4 \mathrm{~mm}$, previously measured with a Paiva's condenser with a cursor. The roots were then immediately immersed in $0.2 \%$ Rhodamine B aqueous solution, kept in an oven at $37^{\circ} \mathrm{C}$ in relative humidity of $100 \%$, for 72 hours. After this period, the roots were removed from the dye and washed in tap water for 12 hours, then they were dried and the coat was removed with a Le Cron spatula. In the sequence, longitudinal grooves were performed on the buccal and palatal aspects of the roots, making use of a steel disc to approach the root canal obturation, then cleavage was performed with a Le Cron spatula to obtain the hemisection. Dye leakage was measured by using a reflected light microscope with a micrometric ocular (planimetry technique). Those measurements were directly obtained with the scale contained into the micrometric ocular, whose results expressed in parts were transformed in millimeters, applying a simple rule of three. The mean leakage in millimeters was properly tabulated and globally compared by the one-way ANOVA at the significance level of $5 \%$. Whenever a significant difference was observed in the global comparison, 2 by 2 comparison was performed by the Tukey test.

\section{RESULTS}

TABLE 1 and FIGURE 1 represent the means (in $\mathrm{mm}$ ) of leakage in the 3 groups, whose values demonstrate a disadvantage for GROUP I (CIMPAT).

Random Analysis of Variance, at the significance level of $5 \%$ (TABLE 2), evaluated the significance of difference among the assessed groups. The means of the results were compared, two by two, with application of the Tukey test. These comparisons are presented in TABLE 3, among the means of the observed groups: Cimpat cement, IRM and Vidrion R. Cimpat cement allowed significant leakage in

\footnotetext{
a Spécialités Septodont; Paris, France;

b Dentsply - Ind. e Com. Ltda - Petrópolis - RJ, Brazil;

c SS White - Artigos Dentários Ltda - Rio de Janeiro - RJ, Brazil;
} 
relation to IRM and Vidrion R, and there was no significant difference between IRM and Vidrion R. (Table 1), (Figure 1), (Table 2), (Table 3).

\section{DISCUSSION}

The choice of a temporary filling material is important for an efficient coronary sealing between sessions of endodontic treatment, avoiding exposure of the pulp cavity to the oral environment. That care must also be observed in the preparation for root posts, whose remaining obturation must be well protected to avoid contamination by contact with the oral fluids, which could lead to failure of endodontic treatment ${ }^{19}$.

Temporary filling cements must offer appropriate properties, considering that many times, after obturation and preparation for root posts, the patient postpones fabrication of the prosthesis. The choice of materials for

TABLE 1- Demonstration of the amount, mean in $\mathrm{mm}$ and variance

\begin{tabular}{c|c|ccc|c}
\hline Group & Cement & Count & Amount & Mean & Variance \\
\hline Group I & CIMPAT & 20 & 51.6 & 2.58 & 0.766 \\
\hline Group II & IRM & 20 & 34.18 & 1.71 & 0.288 \\
\hline Group III & VIDRION R. & 20 & 34.94 & 1.75 & 0.1334
\end{tabular}

TABLE 2- Randon analysis of variance (ANOVA)

\begin{tabular}{c|c|c|c|cc|c}
\hline $\begin{array}{c}\text { Source of } \\
\text { variation }\end{array}$ & $S Q$ & GI & $M Q$ & $F$ & P value & Critical F \\
\hline Among groups & 9.693 & 2 & 4.847 & 12.246 & $0.000038^{*}$ & 3.159 \\
\hline Within groups & 22.559 & 57 & 0.396 & & & \\
\hline Total & 32.253 & 59 & & & & \\
\hline
\end{tabular}

*Significant difference at $\mathrm{p}<0.05$

TABLE 3- Tukey test

\begin{tabular}{l|c|c|c}
\hline & GROUPI & GROUP II & GROUP III \\
GROUP I & $M=2.58$ & $M=1.709$ & $M=1.747$ \\
\hline GROUP II & & $0.000259^{*}$ & $0.000392^{*}$ \\
\hline
\end{tabular}

Significant difference at $\mathrm{p}<0.05$

\section{Mean leakage (mm)}

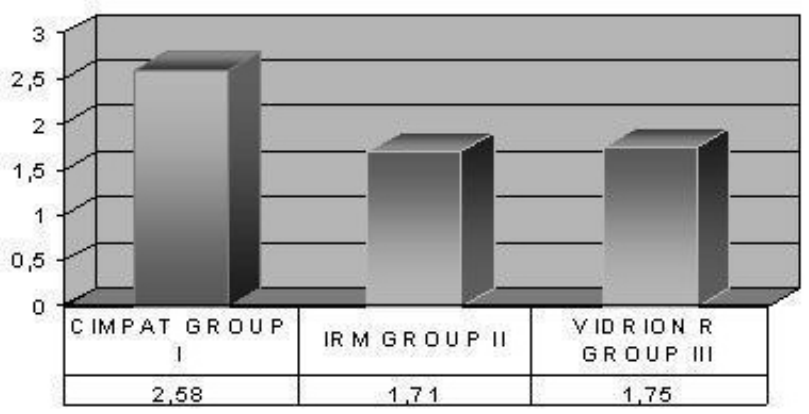

FIGURE 1- Grafic representation of mean leakage this experiment was based on the materials most used by different professionals and more easily found in the specialized trade.

The depth of the cavity to receive the cement should be observed by the professional, because the material should have a certain thickness to allow correct sealing. It is important to highlight that when there is dye leakage, there will not be bacterial leakage as a rule, because these are larger (4 to 6 micrometers) than the dye ions. Besides, some temporary filling materials present bacteriostatic property and, in the case of leakage, it would avoid bacterial proliferation.

With the expectation to find a cement that presents the smallest leakage, protecting the root canal from saliva contamination, we selected materials routinely used in the Endodontics clinic.

Our results demonstrated that sealing with Cimpat (Group I) presented a significantly high leakage (TABLE 3) in relation to IRM cements (Group II) and Vidrion R (Group III). In general, the literature presents better results for Cimpat; however, the experiments of Sousa et al. ${ }^{18}(1994)$, Paula et al. ${ }^{14}$, (1994) and Oliveira ${ }^{13}$ (2001), using thermal cycling, which simulates the thermal unbalances that happen in the mouth with the ingestion of cold and hot foods, they obtained similar results, that is, high leakage values for Cimpat. The discrepant results found in the literature for the referred cement can be related to different methodologies applied, thickness of the cement and its condensation in the cavity. According to the present methodology, the white Cimpat cement was seated in the thickness of $4 \mathrm{~mm}$ without the concern of effective condensation and it must probably have been the cause of the larger leakage in relation to the other materials.

Group II, represented by the IRM cement, was better than Cimpat, different from IRM, which has low resistance; its surface presents wear in short term and can evidently interfere with maintenance of sealing ${ }^{10}$. The results achieved with the IRM (TABLE 1) are in agreement with those observed by Bramante; Berbert; Bernardineli ${ }^{3}$ (1977) and Jacquot et al. ${ }^{12}$ (1996), who found good sealing for this material. It must be pointed out that in the experiment of Bramante; Berbert; Bernardineli ${ }^{3}$ (1977) a more refined methodology was used, making use of the $\mathrm{I}^{131}$, in which the specimens were immersed for 24 hours for $37^{\circ} \mathrm{C}$. The sealer ability of IRM was also observed with different powder/ liquid ratios and using thermal cycling.

The microleakage values obtained for the glass ionomer cement were slightly larger than the values found for IRM, yet not statistically significant (TABLE 3). On the other hand, in relation to Cimpat, the difference was significant (TABLE $3)$. The chemically cured glass ionomer cements promote good sealing at the dentin/sealer interface, reducing the fluid movement inside the dentinal tubules ${ }^{7}$. The use of chemically cured glass ionomer cements for temporary filling is recent. Those cements are advantageous compared to cements as IRM due to the chemical adhesion to the tooth structure $^{4}$ and fluoride release ${ }^{17}$, which is very important in the prevention of carious lesions. 
In this study, as roots were used, without concern on the number of walls and resistance to the masticatory force, a sealing of $4 \mathrm{~mm}$ of thickness was applied, based on experimental discoveries of Fidel et al. ${ }^{6}$, who reported that in cases of an endodontic cavity without one or more walls, the professional should use a temporary filling cement that may be bonded to the dentin, is resistant to masticatory forces and not soluble in the oral fluids, highlighting that, in the case of roots, the material must be contained by the cavity walls. The literature demonstrates experiments with temporary filling materials in the thickness of 2.0 to $3.0 \mathrm{~mm}$, accomplished by Grossman ${ }^{9}$ (1939) in glass tubes, showing that by that time there was already concern with marginal leakage. In other study, Roghanizad, Jones ${ }^{16}$ (1996) used thermal cycling and placement of temporary filling materials with thickness of 3mm, and the results demonstrated good sealing of the roots with the advantage of being relatively easily removed. On the other hand, Deveaux et al. ${ }^{5}$ (1992), demonstrated that thermal cycling and the thickness of sealing of Cavit, 3.75mm; IRM, 3.45mm; and Term, 5.49 did not prevent leakage in the filling.

The choice of temporary filling material must be based on the sealing ability and if possible even on the antibacterial action. Zinc oxide-eugenol cements present good sealing ability, resistance and satisfactory antibacterial activity, though its eugenol content can interfere with the adhesiveness of composite resins (8) and that fact must be considered in the fixation of some posts with resin. However, zinc oxide-eugenol cements, as IRM, are frequently used because it gathers the qualities mentioned above, as well as for its low cost in comparison to chemically cured glass ionomer cements. Temporary filling cements, like Cimpat, are easy to apply, though they are not resistant to masticatory forces and their sealing ability is inferior to IRM and to the chemically cured glass ionomer.

\section{CONCLUSION}

According to the results it can be concluded that:

1) The sealing ability of IRM and Vidrion R, respectively temporary and restorative materials, was superior to the temporary cement Cimpat.

2) The temporary cement IRM and the restorative cement Vidrion $\mathrm{R}$ presented similar sealing ability.

\section{REFERENCES}

1- Alves J, Walton R, Drake D. Coronal leakage: Endotoxin penetration from mixed bacterial communities trought obturated post prepared root canals. J Endod. 1998;24(9):587-91.

2- Barthel CR, Strobach A, Briedigkeit H, Gobel UB, Roulet JF. Leakage in roots coronally sealed with different temporary fillings. J Endod. 1999;25(11):731-4.

3- Bramante CM, Berbert A, Bernardineli N. Materiais seladores provisórios: avaliação das propriedades seladoras $\mathrm{I}^{131}$. Rev Paul Cirurg Dent. 1977;31(2):10-3.
4- Candido MSM, Moraes PB, Rodrigues Junior AL. Avaliação da infiltração marginal do cimento de ionômero de vidro em cavidades de classe V. Efeito de tratamento de secagem da dentina. J Bras Odontol Clin. 1996;3(13):24-9.

5- Deveaux E, Hildelbert P, Neut C, Boniface B, Romond C. Bacterial microleakage of Cavit, IRM, and Term. Oral Surg Oral Med Oral Pathol. 1992;74(5):634-43.

6- Fidel RAS, Fidel SR, Cruz Filho AM da, Vansan LP, Pécora JD. Avaliação "in vitro" de alguns materiais seladores provisórios, relacionando-os com as condições das cavidades endodônticas. Rev Bras Odontol. 1991;48(6):33,36,38.

7- Fraga RC, Siqueira Junior JF. Uso do ionômero de Vidro como “liner”. Rev Gaúcha Odontol. 1995;43(1):41-4.

8- Fraga RC, Vasconcelos BT de, Siqueira Júnior JF, Fraga LR de L. Ação de um adesivo hidrofílico em dentina tratada com selador temporário contendo eugenol. Âmbito Odontol. 1996;5(31):5-10.

9- Grossman LI. A study of temporary fillings as hermetic sealing agents. J Dent Res. 1939;2(18):67-71.

10- Holland R, Nery MJ, Souza V. de, Bernabé PFE, Mello W de, Pannain R. Propriedade seladora de alguns materiais obturadores temporários. Rev Paul Cirurg Dent. 1976;30(4):175-8.

11- Holland R, Dezan Junior E, Yanagihara VY, Souza V de, Saliba O. Avaliação da infiltração marginal de materiais seladores temporários: influência do emprego do vácuo. Rev Gaúcha Odontol. 1992;40(1):2932 .

12- Jacquot BM, Panighi MM, Steinmetz P, G'Sell C. Microleakage of Cavit, Cavit W, Cavit G and IRM by impedance spectroscopy. Int Endod J. 1996;29(4):256-61.

13- Oliveira, ECG. Avaliação in vitro da infiltração marginal de alguns materiais seladores provisórios utilizados na Endodontia. Ribeirão Preto; 2001. [Dissertação de Mestrado - Faculdade de Odontologia de Ribeirão Preto da USP]

14- Paula EAS de, Fidél RAS, Fidél SR, Gurgel Filho ED. Estudo “in vitro" da infiltração de alguns materiais seladores provisórios usados em endodontia. Odontol Mod. 1994;21(5):15-6.

15- Polo I, Lage Marques JL da S, Cardoso RJA, Antoniazzi JH. Selamento marginal cervical simples e duplo em endodontia. Rev Paul Cirurg Dent. 1996;50(5):435-9.

16- Roghanizad N, Jones JJ. Evaluation of coronal microleakage after endodontic treatment. J Endod.1996;22(9):471-3.

17- Siqueira Junior JF, Fraga RC, Lopes, HP. Evaluation of the antibacterial activity of temporary sealing materials. JBC - Jornal Brasileiro de Clínica \& Estética em Odontologia. 1996;3(15):67-9.

18- Sousa SMG de, Bramante, AS, Bramante CM. Materiais seladores temporários. Rev Gaúcha Odontol. 1994;42(6):311-4.

19- Torabinejad M, Ung B, Kettering JD. In vitro bacterial penetration of coronally unsealed endodontically treated teeth. J Endod. 1990;16(12):566-9. 